\title{
Relative sensitivity of mice to inhaled ozone and cigarette smoke exposure
}

\author{
Rachel A Armstrong*, Stephen M Jordan, Emma McConnell, Robert Carrington, Debbie Rodgers, \\ Kenneth G Meecham \\ From 2nd Cross Company Respiratory Symposium \\ Horsham, UK. 6-7 September 2012
}

Inhaled exposure of both the environmental pollutant ozone and cigarette smoke are important risk factors in the development of chronic obstructive pulmonary disease. We assessed the relative pulmonary sensitivity of mice following ozone challenge in comparison to acute cigarette smoke exposure.

For ozone, mice were exposed to a single 3 hour whole body challenge of 3, 7 and $10 \mathrm{ppm}$. Animals were sacrificed at either 4 or 24 hours post-exposure. For the acute cigarette smoke model, mice (BALB/c and C57BL6) were exposed to 250,600 and $800 \mu \mathrm{g} / \mathrm{L}$ particulate concentration for 60 minutes twice daily over a four day period. Air was used as control. Animals were sacrificed 24 hours following the final exposure. Recruitment of inflammatory cells to the lung was assessed in BALF by flow cytometry. Inflammatory responses and anti-inflammatory effects of a corticosteroid and PDE4 inhibitor were assessed.

Ozone exposure induced a concentration dependent neutrophilia with a 3 -fold increase at $3 \mathrm{ppm}(0.19 \pm 0.03$ v $0.54 \pm 0.12 \times 10^{5}$ cells/animal) peaking at $0.73 \pm 0.10$ $\mathrm{x} 10^{5}$ cells/animal 4 hours following $10 \mathrm{ppm}$ exposure. Similar neutrophil counts were recorded at 4 and 24 hours post-exposure. Increased BALF macrophage counts were also recorded but only following $10 \mathrm{ppm}$ challenge $\left(0.74 \pm 0.11 \mathrm{v} 2.44 \pm 0.34 \times 10^{5}\right.$ cells/animal $)$ at 24 hours post challenge. Intervention with budesonide (at a dose regime that produces $90 \%$ inhibition of LPS induced BALF neutrophilia) did not inhibit cellular recruitment.

Repeated exposure to cigarette smoke induced a concentration and time dependent neutrophilia in BALB/c mice reaching statistical significance as early as Day 2 following exposure at $600 \mu \mathrm{g} / \mathrm{L}$. Comparatively C57BL6

Department of Pharmacology, Huntingdon Life Sciences, Cambridgeshire, UK mice were insensitive to cigarette exposure with at least a 5-fold lower response at the identical exposure concentrations. Cigarette smoke induced neutrophilia was also steroid-insensitive.

Published: 14 August 2013

doi:10.1186/1476-9255-10-S1-P27

Cite this article as: Armstrong et al:: Relative sensitivity of mice to inhaled ozone and cigarette smoke exposure. Journal of Inflammation 2013 10(Suppl 1):P27.
Submit your next manuscript to BioMed Central and take full advantage of:

- Convenient online submission

- Thorough peer review

- No space constraints or color figure charges

- Immediate publication on acceptance

- Inclusion in PubMed, CAS, Scopus and Google Scholar

- Research which is freely available for redistribution
() Biomed Central 